\title{
Chemical and physical fractions of soil organic matter under various management regimes in Roraima, Brazil
}

\section{Frações químicas e físicas da matéria orgânica do solo sob diferentes sistemas de uso em Roraima}

\author{
Marden Daniel Espinoza Guardiola ${ }^{1}$; José Frutuoso do Vale Júnior²; Edmilson \\ Evangelista da Silva ${ }^{3}$; Celeste Queiroz Rossi ${ }^{4}$; Marcos Gervasio Pereira ${ }^{5 *}$
}

\begin{abstract}
The crop-livestock integration (CLI) and crop-livestock-forest integration (CLFI) management systems, have been shown to be viable approaches for increasing carbon sequestration in soils, resulting in the improvement of physical and chemical soil attributes. The objective of this study was to evaluate the chemical attributes and organic matter in soils under Natural Forest (NF) converted to different uses and managed differently: rotational pasture area (PAST), crop-livestock integration (CLI), and croplivestock-forest integration (CLIF). The research was conducted at the São Paulo farm, in Iracema, located in the south-central region of the state of Roraima, Brazil. The studied soil type was classified as Ultisol. Soil samples were taken by opening ditches and examining layers at $0.1-\mathrm{m}$ depth intervals from surface to $0.60-\mathrm{m}$ depth. Total organic carbon (TOC), chemical and granulometric fractionation of soil organic matter (SOM), oxidizable fractions, and light organic matter in water were analyzed. Our results showed low levels of the analyzed chemical elements, a characteristic of a soil with low natural fertility. This matches conditions inherent in source material, weathered by high rainfall, a warm and humid climate, and flat topographic relief. In the 0-0.1 m layer, the PAST and CLI systems had the highest TOC contents relative to the other systems studied. At other depths, there were no statistical differences among TOC levels. The highest concentration of $\mathrm{C}$ in the particulate fraction (POC) was noted in the surface layer in all management systems. The pasture system had the highest concentration POC in the top $0.10 \mathrm{~m}$. Our results also showed that the upper $0.10 \mathrm{~m}$ of soil in NF contained the lowest content of organic carbon associated with mineral (MOC) relative to the managed agrosystems. In addition, humin provided the largest contribution to SOM in all evaluated management systems. The crop-livestock integration (CLI) and crop-livestock integration forest (CLIF) systems, emerged as a strong alternative to carbon incorporation and subsequently the improvement of physical and chemical soil attributes. The objective of this work to evaluate the chemical attributes and organic matter in soils under Natural forest (NF) converted into different use and management systems: pasture (PAST), croplivestock Integration (CLI) and crop-livestock Integration forest (CLIF). The research was conducted at São Paulo farm in Iracema, located in the Center-South region of the State of Roraima, Brazil. The soil studied was classified as Argissolo Amarelo Distrófico. The samples were taken by the opening
\end{abstract}

1 Prof. Auxiliar, Centro Universitário Regional del Litoral Atlántico, CURLA, Universidad Nacional Autónoma de Honduras, UNAH, La Ceiba, Honduras. E mail: marden.espinoza@unah.edu.hn

2 Professor Titular do Centro de Ciências Agrárias, Universidade Federal de Roraima, UFRR, Boa Vista, RR, Brasil. E mail: valejr51@gmail.com

3 Pesquisador, Empresa Brasileira de Pesquisa Agropecuária, EMBRAPA Roraima, Boa Vista, RR, Brasil.Email: edmilson.e.silva@ embrapa.br

4 Pós-Doutoranda, Curso de Pós-Graduação em Agronomia, Ciência do Solo, CPGA/CS, Universidade Federal Rural do Rio de Janeiro, UFRRJ, Seropédica, Rio de Janeiro, Brasil. Bolsista Faperj. E mail: celesteqrossi@yahoo.com.br

5 Prof. Titular, Departamento de Solos, UFRRJ, Bolsista do CNPq, Seropédica, RJ, Brasil. E mail: mgervasiopereira01@gmail. com

* Author for correspondence

Received: Oct. 30, 2016 Approved: Feb. 16, 2017 
of trenches in layers of $0-0.10,0.10-0.20,0.20-0.40$, and $0.40-0.60 \mathrm{~m}$ depth. Total organic carbon (TOC), chemical and granulometric fractionation of soil organic matter (SOM), oxidizable fractions and organic matter in water were analyzed. The results showed low levels of the analyzed chemical elements which characterizes soils with low natural fertility, which matches the conditions of the source material, high rainfall and regional temperature, as well as the flat local relief. In the 0-0.1 m layer, the PAST and CLI systems had the highest TOC contents when compared to the other systems studied, in the other depths there were no statistical differences between the TOC levels. The highest amount of $\mathrm{C}$ in the particulate fraction (COp) was verified in the surface layer in all evaluated management systems. The pasture area was the system with the greatest contribution of COp to the depth of $0-0.0 \mathrm{~m}$. In relation to the carbon content associated with minerals (COam), the results showed that the depth of 0-0.05 m NF area presented the lowest levels when compared to the other systems. Regarding the humic substances, there was a larger contribution of humin in all evaluated systems.

Key words: Soil Fertility. Organic Carbon Fractionation. Characterization of Soil Organic Matter.

\section{Resumo}

Os sistemas de integração lavoura-pecuária (ILP) e lavoura-pecuária floresta (ILPF) surgiram como forte alternativa para incorporação de carbono e consequentemente melhoria nos atributos físicos e químicas do solo. Objetivou-se com o presente trabalho avaliar os atributos químicos e matéria orgânica em solos sob Floresta Natural (FN) convertidos em diferentes sistemas de uso e manejo: pastagem (PAST), Integração lavoura-pecuária (ILP) e Integração lavoura-pecuária floresta (ILPF). O estudo foi realizado na fazenda São Paulo, em Iracema, localizada na região centro-sul do estado de Roraima. O solo estudado foi classificado em Argissolo Amarelo Distrófico. As amostras foram retiradas mediante a abertura de trincheiras nas camadas de 0-0,10, 0,10-0,20, 0,20-0,40 e 0,40-0,60 m de profundidade. Foram analisados o carbono orgânico total (COT), fracionamento químico e granulométrico da MOS, as frações oxidáveis e a matéria orgânica leve em água. Os resultados mostraram baixos teores dos elementos químicos analisados, o que caracteriza solos com baixa fertilidade natural, que condiz com as condições do material de origem, elevadas precipitações e temperatura regional, bem como ao relevo local plano. Na camada de $0-0,10 \mathrm{~m}$ os sistemas PAST e ILP apresentaram os maiores teores de COT quando comparados aos outros sistemas estudados, nas demais profundidades não se verificou diferenças estatísticas entre os teores de COT. A maior quantidade de $\mathrm{C}$ na fração particulada (COp) foi verificada na camada superficial em todos os sistemas de manejo avaliados. A área de pastagem foi o sistema com a maior contribuição do COp na profundidade de $0-0,10 \mathrm{~m}$. Com relação aos teores do carbono associado aos minerais (COam), os resultados demostraram que na profundidade de 0-0,10 m, área de FN apresentou os menores teores quando comparados aos outros sistemas. Em relação às substâncias húmicas houve uma maior contribuição da Humina em todos os sistemas avaliados.

Palavras-chave: Fertilidade do solo. Fracionamento do Carbono Orgânico. Caracterização da Matéria Orgânica do Solo.

\section{Introduction}

It has been evident in recent years that economic advancement, agricultural production, and increased use of inputs worldwide have led to increased deforestation and conversion of natural areas to agricultural lands commercial crops. Maintaining soil quality is one of the key mechanisms for achieving long-term sustainability of agricultural systems and emphasizing sustainable land management is the main approach for preserving soil organic matter (CAETANO et al., 2013).

Soil organic matter (SOM) is one of the most important constituents maintaining tropical soil fertility. SOM formation occurs through the decomposition of plants and animals, during a constant process of transformation and synthesis. This is a key process for the sustainable maintenance of terrestrial ecosystems (BENITES et al., 2010). 
The types of SOM and chemical characteristics of soil are directly linked and change according to the type of management practices adopted (CARVALHO et al., 2010). In general, the main obstacles to maintaining soil quality in tropical soils, especially for the majority of Oxisol and Ultisol, are their low total cation-exchange capacities (CEC), high phosphorus-binding, and toxic aluminum concentrations $\left(\mathrm{Al}^{3+}\right)$. However, these drawbacks may be reduced with input and preservation of soil organic carbon content (BALDOTTO et al., 2015).

The use of systems with different inputs of plant biomass can be revealed through particulate fraction of SOM, in a way that it is possible to use it as an indicator to measure soil quality, especially in a short period (CONCEIÇÃO et al., 2005; ROSSI et al., 2012). However, it is crucial to identify the different fractions, as well as the forms of protection under natural vegetation and various agro-management systems (FIGUEIREDO et al., 2010).

Converting natural areas to agriculture, with the resulting reduction of natural vegetation, can reduce the content of SOM, causing a loss in soil fertility, and increased erosion (BERNOUX et al., 2004). However, the adoption of conservation management practices that prioritize the input and maintenance of SOM levels may also contribute to the sequestration of C. Crop-livestock integration systems, no-tillage management, the use of cover crops and fallow system, crop rotation, various agroforestry systems, among others, are all examples of such systems that contribute to $\mathrm{C}$ sequestration (FERREIRA et al., 2012; PAUL et al., 2013).

Crop-livestock integration management systems can be characterized by four basic types: (1) croplivestock integration (CLI), or agro-pastoral systems, is a production type that associates the agricultural and livestock components in a rotational, union, or successional pattern, in the same area and in the same agronomic year, or over multiple years; (2) livestock-forest integration (LFI), or silvo-pastoral system, is a production type that integrates livestock (pasture and animal) and forestry components in a consortium; (3) crop-forest integration (CFI) or silvo-agricultural system, is a production type that integrates forest and agricultural components, in a consortium of tree species with agricultural crops (annual or perennial); and, (4) crop-livestock-forest integration (CLFI), which is a production type that associates, in the same area, agricultural, livestock, and forestry components in a rotational, consortium, or successional pattern (BALBINO et al., 2011).

Recently, the adoption of crop-livestock integration (CLI) and crop-livestock-forest integration (CLFI) have been found to provide better conservation of soil chemical and physical attributes in some regions of Brazil (FRAZÃO et al., 2010; SALES et al., 2010). These systems have been used as a tool to restoredegraded areas because they allow for a diversification of production (agricultural, livestock, and forest management systems) in the same area, which in turn improves the physical, chemical, and biological characteristics of soils, increases nutrient cycling capacity, reduces crop production costs, increases the income of the producer, decreases the pressure for deforestation of new areas with native forests, and reduces the emission of greenhouse gases; therefore, all these management systems improve the soil carbon cycle.

A significant increase has been observed in the adoption of integrated cropping systems, such as CLI, which have a considerable potential for soil $\mathrm{C}$ accumulation. According to Kluthcouski and Oliveira (2012), the use of perennial grasses in CLI, such as brachiarias, whether in a consortium, succession, or rotation with annual crops, can minimize soil degradation, due to the beneficial effect of these grasses have on physical attributes of soils. It can also increase the soil C stock and reduce greenhouse gas emissions to the atmosphere.

Soil chemical attributes and TOC fractions have been considered indicators of soil quality among areas with differing agro-management systems (in several Biomes). Therefore, this study aimed 
to evaluate the chemical and physical fractions of soil organic matter in Argissolo Amarelo Distrófico (Ultisol) soils, among various systems of land use and management in the municipality of Iracema Roraima, Brazil.

\section{Material and Methods}

Our study was carried out at the São Paulo farm in Iracema, located in the south-central region of the state of Roraima $\left(2^{\circ} 17^{\prime} 36.30^{\prime \prime} \mathrm{N}\right.$ and $\left.61^{\circ} 14^{\prime} 50.39^{\prime \prime} \mathrm{W}\right)$, in the community of Roxinho,
Brazil. The region of the study comprises a transitional bioclimatic scenario in the Amazon. According to the classification of Köppen, the climate of the southern portion is defined as Am (Tropical Monsoon) and transitions to Aw (Tropical Wet and Dry or Savannah) in the northern portion (BARBOSA, 1997). The studied soils were classified as Argissolo Amarelo Distrófico (Ultisol), according to the Brazilian System of Soil Classification - SiBCS (SANTOS et al., 2013), with a texture ranging from medium to clayey (Table 1).

Table 1. Granulometric composition of soils under different management systems, seven years after implementation, in the Semidecidual Seasonal Forest Region, Roraima, Brazil.

\begin{tabular}{|c|c|c|c|c|}
\hline \multirow{2}{*}{$\begin{array}{c}\text { Depth } \\
\text { (m) }\end{array}$} & \multirow[t]{2}{*}{ Treatments } & Clay & Silt & Sandy \\
\hline & & \multicolumn{3}{|c|}{$\mathrm{g} \mathrm{kg}^{-1}$} \\
\hline \multirow{4}{*}{$0-0,10$} & PAST & 270 & 176 & 554 \\
\hline & NF & 181 & 141 & 678 \\
\hline & CLI & 240 & 154 & 476 \\
\hline & CLFI & 248 & 215 & 536 \\
\hline \multirow{4}{*}{$0,10-0,20$} & PAST & 372 & 128 & 500 \\
\hline & NF & 289 & 137 & 574 \\
\hline & CLI & 291 & 232 & 476 \\
\hline & CLFI & 321 & 215 & 494 \\
\hline \multirow{4}{*}{$0,20-0,40$} & PAST & 402 & 109 & 488 \\
\hline & NF & 354 & 221 & 425 \\
\hline & CLI & 376 & 233 & 391 \\
\hline & CLFI & 385 & 151 & 463 \\
\hline \multirow{4}{*}{$0,40-0,60$} & PAST & 462 & 88 & 450 \\
\hline & NF & 435 & 96 & 469 \\
\hline & CLI & 329 & 206 & 464 \\
\hline & CLFI & 426 & 109 & 465 \\
\hline
\end{tabular}

PAST (rotational pasture area), NF (natural forest), CLI (crop-livestock integration system), and CLFI (crop-livestock-forest integration system).

Our experiment was conducted in 2009, in an area previously occupied by Natural Forest (NF). The study area covered a total area of 58 ha, which included a crop-livestock-forest integration management system (CLFI) of 15.6 ha, a croplivestock integration system (CLI) of 8.5 ha, and a rotational pasture system (PAST) of 33.9 ha. The natural vegetation (NF) is a Semidecidual Seasonal Forest and was used as a control for the other agrosystems studied.

The preparation of the CLI and CLFI areas were made through the plowing and incorporation of $1500 \mathrm{~kg} \mathrm{ha}^{-1}$ of dolomitic limestone, $50 \mathrm{~kg} \mathrm{ha}^{-1}$ of FTE BR 12 and $90 \mathrm{~kg}$ of $\mathrm{P}_{2} \mathrm{O}_{5}$ in the form of single superphosphate.

In the CLFI management system, trees were planted NE-SW in five rows spaced by $70 \mathrm{~m}$, in 
various arrangements relative to the planted species: Cedro espino (Bombacopsis quinata), Teak (Tectona grandis), Taxi (Sclerolobium paniculatum), and Gliricidia (Gliricidia sepium). The spacing within the alleys (non-tree areas) were $3 \times 4 \mathrm{~m}$, but where there were external lines of Gliricidia (at the edges of the alleys), these trees were spaced by 1 m. Urochloa brizantha 'Marandu' was used as forage, intercropped with rice, among the alleys and received 90, 72, and $90 \mathrm{~kg} \mathrm{ha}^{-1}$ of $\mathrm{N}_{2} \mathrm{P}_{2} \mathrm{O}_{5}$, and $\mathrm{K}_{2} \mathrm{O}$, respectively. Cowpea beans (planted in the interrows of trees in 2009) were fertilized with 18 and 30 $\mathrm{kg} \mathrm{ha}^{-1}$ of $\mathrm{P}_{2} \mathrm{O}_{5}$ and $\mathrm{K}_{2} \mathrm{O}$, respectively. In 2010 and 2011, the soybean crop was planted in the no-tillage system between May 10 and 15. Animals (Cattle) began grazing in the system on November 15, 2009, remaining until April 30 (165 days). In 2010 the grazing occurred from December 15 to April 6, 2011 (130 days). After this period, the areas of CLFI were fenced in and no longer cultivated with grains, thus beginning the period of continuous grazing. The entrance of the animals occurred on November 15,2011 , and by this point in time, the animals had already accessed the tree lines.

In the CLI system, Urochloa brizantha 'Marandu' was used as forage, intercropped with rice, and received 90, 72 and $90 \mathrm{~kg} \mathrm{ha}^{-1}$ of $\mathrm{N}, \mathrm{P}_{2} \mathrm{O}_{5}$ and $\mathrm{K}_{2} \mathrm{O}$, respectively. In 2010 (May 10) and 2011 (May 15) a soybean crop was sown and fertilized, in the CLI system, with 8,96 and $48 \mathrm{~kg} \mathrm{ha}^{-1}$ of $\mathrm{N}$, $\mathrm{P}_{2} \mathrm{O}_{5}$ respectively, and in the coverage were applied $48 \mathrm{Kg}$ ha- 1 of $\mathrm{K}_{2} \mathrm{O}$. The sowing of cover crops alternated between soybean and Panicum maximum 'Tanzania'. After 2011, the system remained in pasture only. Grain planting did not occur again until the date of our sample collections.

In the rotational pasture area (PAST), no correction or soil fertility improvement was performed, only the mowing of the pasture with a scythe. The density of the animals (cattle) corresponded to 60 to 66 individuals per 34 ha, divided into eight fenced pastures, with rotation every five days, within a cycle of 35 days.
The original Semideciduous Seasonal Forest (NF) occurs in environments subjected to periodic water stress, conditioned to variations in rainfall. There is an overlap of the Seasonal Forest type with the occurrence of Argissolos and Latossolos Amarelos and Vermelho-Amarelos (Ultisol and Oxisol) in all areas where this substrate occurs in Roraima. Both soils are well-drained, relatively deep, dystrophic, and heavily weathered, and are located in undulating and gently undulating reliefs. In the study area, species such as Canarywood (Centrolobium paraense), Tatabu (Diplotropis sp.), Marupa (Simarouba amara), Chaste tree (Vitex sp.), Breus (Protium sp.) occur on flat topography. Taperebá (Spondia sp.), Cordia (Cordia sp), Purpleheart (Peltogyne sp.), and Pink trumpet tree (Tabebuia sp.) occur in undulating topography. Kapok (Ceiba pentandra), Tucuma (Astrocaryum aculeatum), Cedro espino (Bombacopsis quinata).

In April 2015, soil samples were collected from trenches at depth intervals of $0-0.10,0.10-0.20$, $0.20-0.40,0.40-0.60 \mathrm{~m}$, using a hoe and a straight shovel, with four replications in each area of the study or treatment type. Collected soil samples were air-dried, stripped, and passed through a 2-mm sieve to obtain air-dried fine ground (ADFG). The determination of the $\mathrm{Ca}^{2+}, \mathrm{Mg}^{2+}, \mathrm{K}^{+}, \mathrm{Na}^{+}, \mathrm{Al}^{3+}$, $\mathrm{H}+\mathrm{Al}, \mathrm{P}$, and $\mathrm{pH}$ values (in water) and granulometry analysis were performed according to Donagemma et al. (2011). The determination of TOC (total organic carbon) followed the methodology of Yeomans and Bremner (1988). The granulometric fractionation was performed according to a methodology proposed by Cambardella and Elliott (1992), and was divided into POC (particulate organic carbon, which consists of the carbon determined in the fraction greater than $0.053 \mathrm{~nm}$ ) and MOC (organic carbon associated with silt and clay minerals, which is calculated by the difference between TOC and POC). The light fraction of the organic matter in water (CMOL) was determined according to the methodology recommended by (ANDERSON; INGRAM, 1989). 
A method for determining oxidizable carbon fractions was proposed by Chan et al. (2001), adapted from the carbon determination method developed by Walkley and Black (1934). In the original method, $\mathrm{C}$ was verified by using a single concentration of sulfuric acid $\left(12 \mathrm{~mol} \mathrm{~L}^{-1}\right)$, but with the change suggested by Chan et al. (2001), it was possible to separate four fractions with decreasing degrees of oxidation. This was done by using increasing amounts of sulfuric acid (i.e., the fractions F1, F2, F3, and F4 were attributed, respectively, to the concentrations of 3, 6, 9, and 12 mol L-1 of sulfuric acid).

Humic substances were quantified using the technique of differential solubility in humic acids (HA), fulvic acids (FA), and humin (HUM), according to the International Humic Substances Society (SWIFT, 1996), using the technique adapted by Benites et al. (2003).

The data were analyzed for normality and homogeneity using the Lilliefors', Cochran's and Bartlett's tests. Next, the data were analyzed as a completely randomized design. The results were submitted to analysis of variance with the application of the F test and the mean values, when significant, were compared with a Tukey's test at 5 $\%$ probability.

\section{Results and Discussion}

The results of the granulometry analysis revealed that the sampled soils range from a medium to clayey texture, with the values of clay increasing with depth (Table 1). These results agree with the geomorphological conditions of the region, as the study area is located in a region of Crystalline Basement rocks (primarly Granite/Gneiss), positioned in a smooth-to-undulating to undulating relief, under Semideciduous Seasonal Forest.

The chemical attributes of the different study areas are presented in Table 2. Despite their similar geologic origin (Granite/Gneiss), the soils formed from these rocks have better chemical quality than soils in the central portion of the state (formed primarily from sedimentary rocks). High rainfall, in association with the local topography (smooth-to-undulating to undulating relief), encourages significant fertility losses (via leaching) throughout the study area, resulting in soils with low natural fertility, high saturation by aluminum, and low saturation by bases. However, the soils do possess adequate morphological and physical characteristics, that when managed to retain fertility, can provide good agricultural production indices (VALE JÚNIOR; LEITÃO SOUSA, 2005).

The $\mathrm{pH}$ values varied from 4.6 to 5.8 , characterizing these soils as moderately acidic (RAIJ; QUAGGIO, 1983). The values of $\mathrm{pH}$ in surface soil (depths of $0.0-0.10$ and $0.10-0.20 \mathrm{~m}$ ) in the PAST, CLI and CLFI systems did not vary statistically; however, they differed statistically from NF, which presented the lowest $\mathrm{pH}$ value at the soil surface. This difference may be due to the fact that soil amendments have never been applied to NF.

The values of potential acidity found corroborate to the $\mathrm{pH}$ values in each of the environments studied, in agreement with the low exchangeable base values found. The highest levels of $\mathrm{Al}^{3+}$ were measured in upper $0.2 \mathrm{~m}$ of NF. The proper use of liming and the reduction of mineral fertilizers in pasture or agricultural systems may result in low levels of aluminum in the soil, and so the high levels of aluminum we found in NF is not surprising. 
Table 2. Chemical characterization of soils under different management systems, seven years after implementation, in the Semidecidual Seasonal Forest Region, Roraima, Brazil.

\begin{tabular}{|c|c|c|c|c|c|c|c|c|}
\hline Treatments & pH em $\mathrm{H}_{2} \mathrm{O}$ & $\mathbf{P}$ & $\mathbf{K}^{+}$ & $\mathrm{Ca}^{2+}$ & $\mathrm{Mg}^{2+}$ & $\mathbf{N a}^{+}$ & $\mathbf{A l ^ { 3 + }}$ & $(\mathrm{H}+\mathrm{Al})$ \\
\hline \multirow{2}{*}{\multicolumn{3}{|c|}{$\mathrm{mg} \mathrm{dm}^{-3}$}} & \multirow{2}{*}{\multicolumn{5}{|c|}{$0-0,10 \mathrm{~m}$}} & \\
\hline & & & & & & & & \\
\hline PAST & $5,7 \mathrm{a}$ & $3,0 \mathrm{~b}$ & $0,15 \mathrm{a}$ & $1,4 \mathrm{a}$ & $1,23 \mathrm{a}$ & $0,13 \mathrm{a}$ & $0,17 \mathrm{~b}$ & $2,2 \mathrm{c}$ \\
\hline NF & $4,6 \mathrm{~b}$ & $3,0 \mathrm{~b}$ & $0,19 \mathrm{a}$ & $0,8 \mathrm{~b}$ & $0,21 \mathrm{~b}$ & $0,12 \mathrm{a}$ & $0,68 \mathrm{a}$ & $3,0 \mathrm{bc}$ \\
\hline CLI & $5,5 \mathrm{a}$ & $10,0 \mathrm{a}$ & $0,25 \mathrm{a}$ & $1,5 \mathrm{a}$ & $0,71 \mathrm{~b}$ & $0,15 \mathrm{a}$ & $0,18 \mathrm{~b}$ & $3,7 \mathrm{ab}$ \\
\hline CLFI & $5,8 \mathrm{a}$ & $10,0 \mathrm{a}$ & $0,24 \mathrm{~b}$ & $1,5 \mathrm{a}$ & $0,47 \mathrm{~b}$ & $0,13 \mathrm{a}$ & $0,18 \mathrm{~b}$ & $4,0 \mathrm{a}$ \\
\hline \multicolumn{9}{|c|}{$0,10-0,20 \mathrm{~m}$} \\
\hline PAST & $5,7 \mathrm{a}$ & $2,0 \mathrm{a}$ & $0,18 \mathrm{a}$ & $0,9 \mathrm{a}$ & $0,83 \mathrm{a}$ & $0,10 \mathrm{a}$ & $0,36 \mathrm{ab}$ & $1,2 \mathrm{~b}$ \\
\hline NF & $4,6 \mathrm{~b}$ & $2,0 \mathrm{a}$ & $0,21 \mathrm{a}$ & $0,5 \mathrm{a}$ & $0,44 \mathrm{a}$ & $0,15 \mathrm{a}$ & $0,56 \mathrm{a}$ & $3,8 \mathrm{a}$ \\
\hline CLI & $5,4 \mathrm{a}$ & $4,0 \mathrm{a}$ & $0,23 \mathrm{a}$ & $1,4 \mathrm{a}$ & $0,20 \mathrm{a}$ & $0,16 \mathrm{a}$ & $0,15 \mathrm{bc}$ & $2,9 \mathrm{a}$ \\
\hline CLFI & $5,7 \mathrm{a}$ & $4,0 \mathrm{a}$ & $0,11 \mathrm{~b}$ & $1,3 \mathrm{a}$ & $0,36 \mathrm{a}$ & $0,08 \mathrm{a}$ & $0,06 \mathrm{c}$ & $1,9 \mathrm{~b}$ \\
\hline \multicolumn{9}{|c|}{$0,20-0,40 \mathrm{~m}$} \\
\hline PAST & $5,7 \mathrm{a}$ & $2,0 \mathrm{a}$ & $0,11 \mathrm{~b}$ & $0,9 \mathrm{a}$ & $0,48 \mathrm{a}$ & $0,11 \mathrm{a}$ & $0,23 \mathrm{~b}$ & $1,3 \mathrm{c}$ \\
\hline NF & $4,8 \mathrm{a}$ & $2,0 \mathrm{a}$ & $0,19 \mathrm{a}$ & $1,0 \mathrm{a}$ & $0,16 \mathrm{a}$ & $0,15 \mathrm{a}$ & $0,67 \mathrm{a}$ & $2,9 \mathrm{ab}$ \\
\hline CLI & $5,3 \mathrm{a}$ & $3,0 \mathrm{a}$ & $0,23 \mathrm{a}$ & $1,3 \mathrm{a}$ & $0,16 \mathrm{a}$ & $0,16 \mathrm{a}$ & $0,23 \mathrm{~b}$ & $3,0 \mathrm{a}$ \\
\hline CLFI & $5,5 \mathrm{a}$ & $1,0 \mathrm{a}$ & $0,12 \mathrm{~b}$ & $0,7 \mathrm{~b}$ & $0,51 \mathrm{a}$ & $0,09 \mathrm{a}$ & $0,31 \mathrm{~b}$ & $1,9 \mathrm{bc}$ \\
\hline C.V \% & 9,07 & 34,51 & 21,2 & 33,53 & 61,41 & 22 & 70 & 18,29 \\
\hline
\end{tabular}

Averages followed by equal letters in the column for the same depth do not differ (Tukey's test at $5 \%$ probability). PAST (rotational pasture area), NF (natural forest), CLI (crop-livestock integration system), and CLFI (crop-livestock-forest integration system).

The mean values of $\mathrm{Ca}^{2+}$ and $\mathrm{Mg}^{2+}$ (Table 2) ranged from 0.5 to $1.5 \mathrm{cmol}_{\mathrm{c}} \mathrm{dm}^{-3}$ for $\mathrm{Ca}^{2+}$ and from 0.16 to $1.23 \mathrm{cmol}_{\mathrm{c}} \mathrm{dm}^{-3}$ for $\mathrm{Mg}^{2+}$. The nutrient contents in soils of CLI, CLFI, and PAST systems were higher than in NF, especially in the $0-0.10 \mathrm{~m}$ depth range. The concentrations of $\mathrm{Ca}^{2+}$ and $\mathrm{Mg}^{2+}$ we measured in the upper $0.4 \mathrm{~m}$ of soil would classify this soil as being low to very low, according to the classification proposed by Araújo et al. (2011). In these soils, the low cation exchange capacity (CEC) is caused by the predominance of low activity clays, associated with low organic carbon content (SOUZA; MELO, 2003). Because the soils are very weathered (i.e., chemical and biological activity have occurred in them for thousands of years), they have lost exchangeable bases, resulting in acidic soils (VENDRAME et al., 2011).

Total organic carbon (TOC) data are presented in Table 3. TOC content decreased in depth and ranged from 4.3 to $15.6 \mathrm{~g} \mathrm{~kg}^{-1}$ in the $0-0.40 \mathrm{~m}$ depth layer, and 4.5 to $0.3 \mathrm{~g} \mathrm{~kg}^{-1}$ at the depth of $0.40-0.60 \mathrm{~m}$.
In the depth range of $0-0.10 \mathrm{~m}$, the PAST and CLI management systems presented the highest TOC levels relative to the other systems studied; at the other depths there were no statistical differences among the TOC levels. Loss et al. (2009) verified that various soil management systems, depending on climatic conditions, provide different amounts of plant residues to the soil. In areas with lower amounts of vegetal remains, associated with hot and humid summers) climatic conditions encourage higher decomposition rates and higher rates of chemical reactions in the soil. Furthermore, rapid mineralization of SOM leads to different TOC levels, especially in upper soil layers.

In studies on the labile and recalcitrant fractions of organic matter in soils under CLI management, Silva et al. (2011) verified that after with 4 and 8 years of production, the systems presented TOC amounts equal to those of a no-tillage system 23 years after implementation. Is this crop rotation of plants of different families in the CLI system 
is associated with a higher input and higher preservation of plant residues. Moreover, grasses, mainly Poaceae, are effective in the contribution and accumulation of carbon in soils, due to its abundant and voluminous root system, which is continually renewed; in addition, the high rhizospheric volume of grass roots increases root activity and modifies in the microbial population (D'ANDRÉA et al., 2004).

Table 3. Total organic carbon (TOC), particulate organic carbon (POC) and organic carbon associated with the minerals (MOC) of soils under different management, seven years after implementation, in the Semidecidual Seasonal Forest Region, Roraima, Brazil.

\begin{tabular}{|c|c|c|c|c|}
\hline \multirow{3}{*}{ Sistemas } & \multicolumn{4}{|c|}{${\text { TOC } \text { g kg }^{-1}}^{-1}$} \\
\hline & \multicolumn{4}{|c|}{ Depth (m) } \\
\hline & $0-0,10$ & $0,10-0,20$ & $0,20-0,40$ & $0,40-0,60$ \\
\hline PAST & $15,6 \mathrm{aA}$ & $7,3 \mathrm{aB}$ & $5,5 \mathrm{aBC}$ & $3,8 \mathrm{aCD}$ \\
\hline NF & $9,3 \mathrm{cA}$ & $7,8 \mathrm{aAB}$ & $5,0 \mathrm{aB}$ & $4,5 \mathrm{aBC}$ \\
\hline CLI & $14,3 \mathrm{abA}$ & $8,5 \mathrm{aB}$ & $4,8 \mathrm{aC}$ & $4,3 \mathrm{aC}$ \\
\hline CLFI & $13,3 \mathrm{bA}$ & $6,7 \mathrm{aB}$ & $4,3 \mathrm{aC}$ & $4,5 \mathrm{aBC}$ \\
\hline \multirow[t]{2}{*}{ C.V.\% } & 18,71 & 27,12 & 17,17 & 17,47 \\
\hline & \multicolumn{4}{|c|}{$\mathrm{POC} \mathrm{g} \mathrm{kg}^{-1}$} \\
\hline PAST & $3,6 \mathrm{aA}$ & $1,5 \mathrm{aB}$ & $1,3 \mathrm{aBC}$ & $1,5 \mathrm{aB}$ \\
\hline NF & $2,3 \mathrm{cA}$ & $1,5 \mathrm{aBC}$ & $1,0 \mathrm{aBC}$ & $0,3 \mathrm{cC}$ \\
\hline CLI & $2,8 \mathrm{bcA}$ & $1,5 \mathrm{aAB}$ & $0,8 \mathrm{aB}$ & $0,8 \mathrm{bcB}$ \\
\hline CLFI & $3,0 \mathrm{bcA}$ & $1,0 \mathrm{aB}$ & $0,8 \mathrm{aB}$ & $0,8 \mathrm{bcB}$ \\
\hline \multirow[t]{2}{*}{ C.V\% } & 49,73 & 45,59 & 50,4 & 43,42 \\
\hline & \multicolumn{4}{|c|}{ MOC g kg ${ }^{-1}$} \\
\hline PAST & $12,0 \mathrm{aA}$ & $5,8 \mathrm{aB}$ & $4,2 \mathrm{aBC}$ & $2,3 \mathrm{aCD}$ \\
\hline NF & $7,0 \mathrm{bA}$ & $6,3 \mathrm{aAB}$ & $4,0 \mathrm{aBC}$ & 4,2 aABC \\
\hline CLI & $11,5 \mathrm{aA}$ & $7,0 \mathrm{aB}$ & $4,0 \mathrm{aC}$ & $3,5 \mathrm{aC}$ \\
\hline CLFI & $10,3 \mathrm{aA}$ & $5,7 \mathrm{aB}$ & $3,5 \mathrm{aC}$ & $3,7 \mathrm{aBC}$ \\
\hline C.V\% & 16,34 & 27,56 & 17,93 & 25,75 \\
\hline
\end{tabular}

Values followed by equal letters (lower case) in the column and equal letters in the row (upper case) for the same variable do not differ (Tukey's test at $5 \%$ probability). PAST (rotational pasture area), NF (natural forest), CLI (crop-livestock integration system), and CLFI (crop-livestock-forest integration system).

Particulate organic carbon (POC) is characterized by particles derived from decomposing plant residues and hyphae of fungi. The permanence of POC in the soil depends on how well the soil is protected physically (LOSS et al., 2011). In our study, the highest amount of $\mathrm{C}$ in the particulate fraction (POC) was verified in the surface layer in all the management systems we evaluated, with values ranging from 3.6 to 1.0 in the surface-to- 0.20 $\mathrm{m}$ layer and from 1.5 to 0.3 in the $0.20-0.60 \mathrm{~m}$ layer (Table 3). Managed pasture was the system with the highest contribution of POC at the $0-0.10 \mathrm{~m}$ depth and its contents were also significantly higher in the 0.40-0.60 m depth range. It is important for soils to maintain adequate amounts of particulate carbon to ensure the flow of carbon to the soil and provide an energy source for microbial activity. In the absence of labile organic matter, carbon oxidation processes decrease carbon stocks, which leads to soil degradation (CAUSARANO et al., 2008).

Studies on soil organic matter fractions under pasture, no-tillage system, and crop-livestock integration management in the Cerrado Goiano Region showed the highest POC content in the 
superficial layer in a CLI system (when compared to pasture and no-till management types). SOM also presented higher levels of POC when compared to the Cerrado in the $0.10-0.40 \mathrm{~m}$ soil layers (GAZOLLA et al., 2015). The authors attributed this result to the use of the brachiarias rotated with a corn crop, since this management type provides a higher annual addition and maintenance of the vegetal residues into the soil surface horizons relative to no-tillage and PAST management types. These results also corroborate with data obtained by Loss et al. (2011) and Rossi et al. (2012), who evaluated no-tillage areas with and without CLI in Latossolo Vermelho (Oxisol) (in the State of Goiás) and found higher POC values in areas of CLI than in no-tillage areas.

Salton et al. (2008), studying the content and dynamics of carbon in soils under CLI, verified the highest amount of $\mathrm{C}$ in the particulate fraction in the surface layer of all management systems. The authors also verified a higher contribution in POC in the pasture area (in the top $0.025 \mathrm{~m}$ stratum), while the conventional planting system had five times lower POC levels.

Our results showed that in the depth range of 0-0.10 m, NF had the lowest $\mathrm{C}$ levels associated with MOC compared to the other management systems we studied. Gazolla et al. (2015) and Loss et al. (2011) verified a higher contribution of the organic carbon fraction associated with the minerals (MOC) in CLI systems in their studies in the Cerrado Goiano. They attributed this results to the use of brachiaria in the CLI system they studied, associated with the $\mathrm{Fe}$ and $\mathrm{Al}$ oxides, which may provide better conditions for the formation of microaggregates, and thus greater protection for the MOC fraction.

The highest contribution of carbon in humic substances occurred in the humin fraction (HUM), to the detriment of the FA and HA fractions in all systems studied (Figure 1). This result may be attributed to the greater participation of humin, which represents about $70 \%$ of the TOC. Humin fractions are considered to be the most recalcitrant portions in the soil and so have a higher potential for interaction with its colloidal mineral matrix (ARAÚJO et al., 2011). In addition, the fractions $\mathrm{AF}$ and $\mathrm{AH}$ are less stable and they are easily mineralized in soil, which reduces their residual content (FONTANA et al., 2006).

At the depth of $0-0.20 \mathrm{~m}$, the PAST and CLI management types presented the highest HUM contents when compared with CLFI and NF types. Barreto et al. (2011), studying cacao cultivation in an Atlantic Forest and a pasture system in Brachiaria, verified that the highest percentage of organic $\mathrm{C}$ was observed in the humin fraction. Likewise, in our study the highest organic $\mathrm{C}$ contents in this fraction were in the pasture area at $0-0.10 \mathrm{~m}$ depth, where the greatest contribution of the fasciculate root system of the grasses occurs. These grasses must raise and maintain soil $\mathrm{C}$ inputs and allow a stabilization of the $\mathrm{C}$ in the humin fraction.

In our study, the highest contribution oxidizable fractions was in F1 fraction, but there were no significant differences between the management systems we evaluated (Figure 2). Among the different management types, only F3, F4 and CMOL fractions were observed, with the lowest levels found in the NF system. 
Figure 1. Humic substances carbon $\left(\mathrm{g} \mathrm{kg}^{-1}\right)$ of soils under different management systems, seven years after implementation, in the Semidecidual Seasonal Forest Region, Roraima, Brazil.

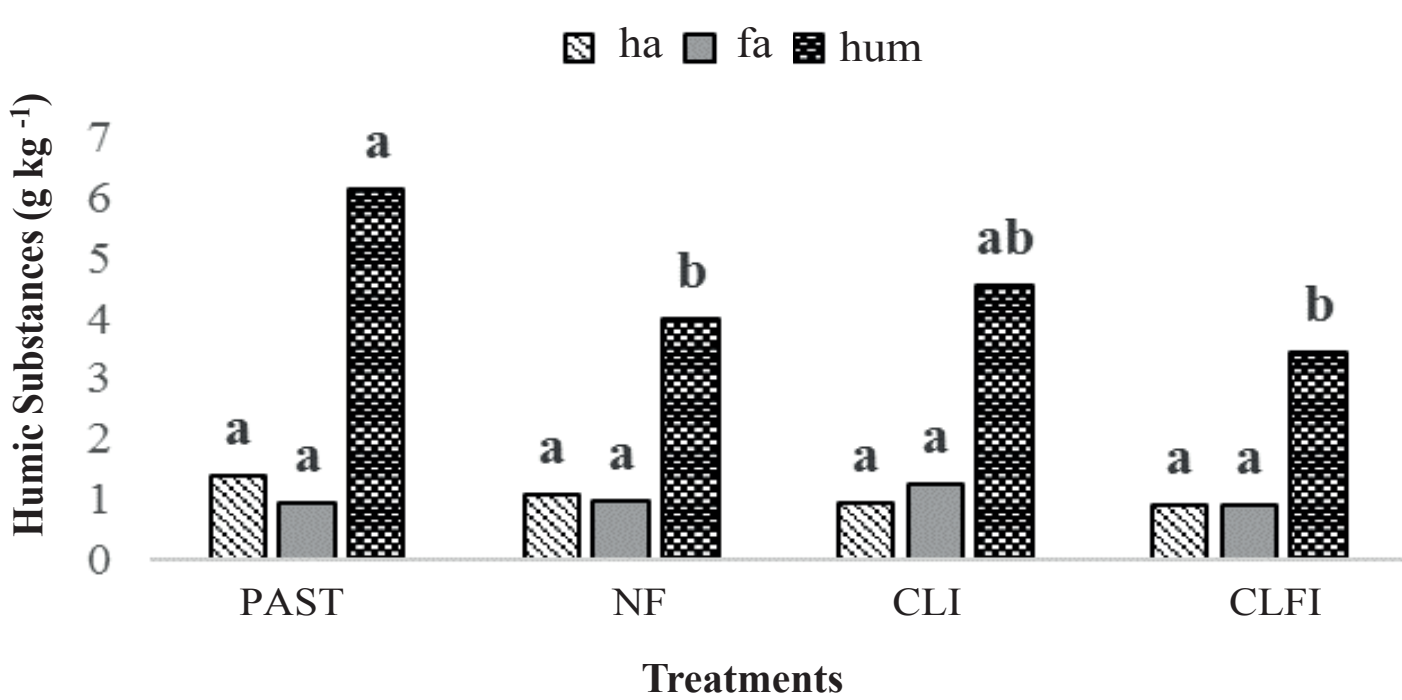

PAST (rotational pasture area), NF (natural forest), CLI (crop-livestock integration system), CLFI (crop-livestock-forest integration system), HA (humic acid), FA (fulvic acid), and Hum (humin). Averages followed by the same letter do not differ (Tukey's test at $5 \%$ probability).

Figure 2. Oxidizable fractions and carbon in the light fraction of the organic matter $\left(\mathrm{g} \mathrm{kg}^{-1}\right)$ of soils under different management systems, seven years after implementation, in the Semidecidual Seasonal Forest Region, Roraima, Brazil.

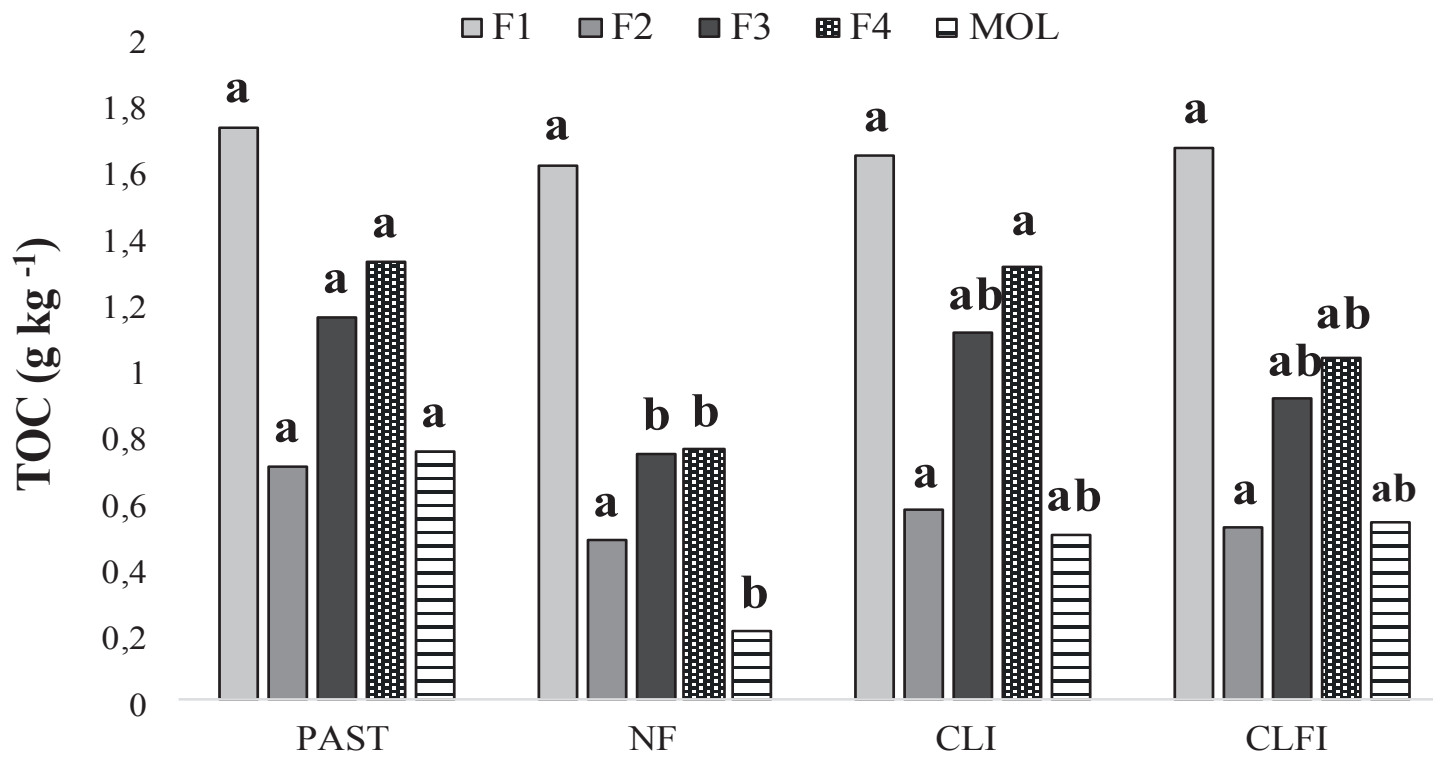

Treatments

PAST (rotational pasture area), NF (natural forest), CLI (crop-livestock integration system), and CLFI (crop-livestock-forest integration system), CMOL (light organic matter in water), and F1, F2, F3, and F4 (fractions of organic matter in different degrees of oxidation at concentrations of 3,6,9 and $12 \mathrm{~mol} \mathrm{~L}^{-1}$ of sulfuric acid, respectively). Averages followed by the same letter do not differ (Tukey's test at $5 \%$ probability). 
The management systems that add organic matter to the soil (via input of decomposition of vegetation) tend to increase the F1 fraction (MORAES et al., 2008) due to the free light fraction of SOM (MAIA et al., 2007). In this study, the highest proportions of TOC occurred in the F1 and F4 fractions. Higher TOC in F4 fraction may be related to a slower release of $\mathrm{C}$, which corresponds to a more resistant fraction of organic carbon. Loss et al. (2009) mentioned that the highest proportions of TOC in F1 and F2 fractions might be mainly attributed to the contribution and decomposition of the most labile plant residues added to the soil. In this case, the permanence of these fractions in soils is low, due to their lower $\mathrm{C} / \mathrm{N}$ ratio, so the more recalcitrant fractions (F3 and F4) decompose more slowly and have a longer half-life in soils.

In integrated production systems, it would be convenient to have a $\mathrm{C}$ balance between the oxidizable fractions, where the proportions of $\mathrm{C}$ between the fractions are similar. Part of the organic matter is more easily decomposed (with higher mineralization rates of nutrients), while another part is more persistent in the soil. The more persistent fraction improves and maintains the physical properties of the soil. However, in tropical regions with sandy-textured soils, hot and humid climates, and a very pronounced rainy season, an increase in the $\mathrm{C}$ content of the more resistant oxidizable fractions (F3 and F4) would be desirable for slower release of nutrients and better crop yields, as well as for improving soil structure (LOSS et al., 2009).

For the F3 and F4 fractions, the CLI, PAST and CLFI management types yielded similar results among management types and were higher than in soils of NF. These results indicate that under the edaphoclimatic conditions of the study area, the evaluated management types have a large part of their TOC distributed in the F3 and F4 fractions. This distribution is related to the presence of compounds with higher chemical stability and molar mass, derived from the decomposition and humification of SOM. Zech et al. (1990) determined that in tropical soils, the bioavailability of the organic matter is less, whereas organic compounds with many aromatic and carboxylic groups is higher.

Our results of CMOL proved that an increase in the contribution of this fraction in the surface layer varies according to the length of time the management system has been in place. After 7 years, soil contents in the $0-0.10 \mathrm{~m}$ layer differed from those observed in the NF. This result indicates the great importance of the CLI and CLFI management systems in the tropics, in that the conservation of CMOL is crucial for the sustainability of tropical environments and their agricultural systems. Our results represent, in short and medium time frames, a high potential for nutrient cycling (COMPTON; BOONE, 2002).

\section{Conclusions}

The studied management systems maintained the total organic carbon contents of their granulometric fractions, in addition, relative to Natural Forest the chemical fractions of the organic matter revealed that, over time, these agro-management systems have a higt potential for sequestering carbon.

Among the humic substances, an humin (HUM) was a more abundant fraction among the types of management we examined. This result may be related to the larger size and complexity of the molecules and to the greater degree of stability of the fraction.

\section{References}

ANDERSON, J. M.; INGRAM, J. S. I. Tropical soil biology and fertility: a handbook of methods. Wallingford: CAB International, 1989. $171 \mathrm{p}$.

ARAÚJO, E. A.; KER, J. C.; MENDONÇA, E. S.; SILVA, I. R.; OLIVEIRA, E. K. Impacto da conversão floresta - pastagem nos estoques e na dinâmica do carbono e substâncias húmicas do solo no bioma Amazônico. Acta Amazônica, Manaus, v. 41, n.1, p. 103-114, 2011.

BALBINO, L. C.; CORDEIRO, M. L. A.; SILVA, V. P.; MORAES, A.; MARTÍNEZ, G. B.; ALVARENGA, R. 
C.; KICHEL, A. N.; FONTANELI, R. S.; SANTOS, P. H.; FRANCHINI, J. C.; GALERANI, P. R. Evolução tecnológica e arranjos produtivos de sistemas de integração lavoura-pecuária-floresta no Brasil Balbino Pesquisa Agropecuária Brasileira. Brasília, v. 46, n. 10, p.1-12, 2011.

BALDOTTO, M. A.; VIEIRA, E. M.; SOUZA, D. de O.; BALDOTTO L. E. B. Estoque e frações de carbono orgânico e fertilidade de solo sob floresta, agricultura e pecuária. Revista Ceres, Viçosa, MG, v. 62, n. 3, p. 301309, 2015.

BARBOSA, R. I. Distribuição das chuvas em Roraima. In: BARBOSA. R. I.; FERREIRA, E. J. G.; CASTELLÓN, E. G. (Ed.). Homem, ambiente e ecologia no Estado de Roraima. Manaus: INPA, 1997. p. 325-335.

BARRETO, P. A. B.; GAMA-RODRIGUES, E. F.; GAMA-RODRIGUES, A. C.; FONTES, A. G.; POLIDORO, J. C.; MOÇO, M. K.; REBOUCA, R. C.; BALIGAR, V. C. Distribution of oxidizable organic $\mathrm{C}$ fractions in soils under cacao agroforestry systems in Southern Bahia, Brazil. Agroforestry Systems, Netherlands, v. 81, n. 3, p. 213-220, 2011.

BENITES, V. M.; MADARI, B.; MACHADO, P. L. O. A. Extração e fracionamento quantitativo de substâncias húmicas do solo: um procedimento simplificado de baixo custo. Rio de Janeiro: Embrapa Solos, 2003. 7 p. (Comunicado técnico, 16).

BENITES, V. D. M.; MOUTTA, O. R. de; COUTINHO, C. L. da; BALIERO, C. F. de. Análise discriminante de solos sob diferentes usos em área de mata atlântica a partir de atributos da matéria orgânica. Revista Árvore, Viçosa, MG, v. 34, n. 4, p. 685-690, 2010.

BERNOUX, M.; CERRI, C. C.; CERRI, C. E. P.; SIQUEIRA NETO, M.; METAY, A.; PERRIN, A.; SCOPEL, E.; BLAVET, D.; PICCOLO, M. C. Influence $\mathrm{du}$ semis direct avec couverture végétale sur la séquestration du carbone et l'érosion au Brésil. Bulletin Du Réseau Érosion, Paris, v. 23, p. 323-337, 2004.

CAETANO, J. O.; BENITES, M. V. de; SILVA, P. G.; SILVA, R. I.; ASSIS, L. R.; CARGNELUTTI, F. A. Dinâmica da matéria orgânica de um Neossolo quartzarênico de cerrado convertido para cultivo em sucessão de soja e mileto. Revista Brasileira de Ciência do Solo, Viçosa, MG, v. 37, n. 5, p. 1245-1255, 2013.

CAMBARDELlA, C. A.; ELLIOTT, E. T. Particulate soil organic-matter changes across a grassland cultivation sequence. Soil Science Society of America Journal, Madson, v. 56, n. 3, p. 777-783, 1992.

CARVALHO, J. L. N.; AVANZI, J. C.; SILVA, M. L. N.; MELLO, C. R.; CERRI, P. C. E. Potencial de sequestro de carbono em diferentes biomas do Brasil. Revista Brasileira de Ciência do Solo, Viçosa, MG, v. 34, n. 2, p. 277- 289, 2010.

CAUSARANO, H. J.; FRANZLUEBBERS, A. J.; SHAW, J. N.; REEVES, D. W.; RAPER, R. L.; WOOD, C. W. Soil organic carbon fractions and aggregation in the Southern Piedmont and coastal plain. Soil Water Management \& Conservation Division, Madson, v. 72, n. 1, p. 221-230, 2008.

CHAN, K. Y.; BOWMAN, A.; OATES, A. Oxidizible organic carbon fractions and soil quality changes in an Paleustalf under different pasture leys. Soil Science, Baltmore, v. 166, n. 1, p. 61-67, 2001.

COMPTON, J. E.; BOONE, R. D. Soil nitrogen transformations and the role of light fraction organic matter in forest soils. Soil Biology and Biochemistry, Elmsford, v. 34, n. 7, p. 933-943, 2002.

CONCEIÇÃO, P. C.; AMADO, T. J. C.; MIELNICZUK, J.; SPAGNOLLO, E. Qualidade do solo em sistemas de manejo avaliada pela dinâmica da matéria orgânica e atributos relacionados. Revista Brasileira de Ciência do Solo, Viçosa, MG, v. 29, n. 5, p. 777-788, 2005.

D'ANDRÉA, A. F.; SILVA, M. L. N.; CURI, N.; GUILHERME, L. R. G. Estoque de carbono e nitrogênio e formas de nitrogênio mineral em um solo submetido a diferentes sistemas de manejo. Pesquisa Agropecuária Brasileira, Brasília, v. 39, n. 2, p. 179-186, 2004.

DONAGEMMA, G. K.; CAMPOS, D. V. B.; CALDERANO, S. B.; TEIXEIRA, W. G.; VIANA, J. H. M. (Org.). Manual de métodos de análise de solo. Rio de Janeiro: CNPS, 2011. 225 p.

FERREIRA, A. O.; MORAES SÁ, J. C.; HARMS, M. G.; MIARA, S.; BRIEDIS, C.; NETTO, C. Q.; SANTOS, J. B.; CANALLI, L. B. Carbon balance and crop residue management in dynamic equilibrium under a no-till system in Campos Gerais. Revista Brasileira de Ciência do Solo, Viçosa, MG, v. 36, n. 5, p. 1583-1590, 2012.

FIGUEIREDO, C. C. de; RESCK, D. V. S.; CARNEIRO, M. A. C. Labile and stable fractions of soil organic matter under management systems and native cerrado. Revista Brasileira de Ciência do Solo, Viçosa, MG, v. 34, n. 3, p. 907-916, 2010.

FONTANA, A.; PEREIRA, M. G.; LOSS, A.; CUNHA, T. J. F.; SALTON, J. C. Atributos de fertilidade e frações húmicas de um Latossolo Vermelho no Cerrado. Pesquisa Agropecuária Brasileira, Brasília, v. 41, n. 5, p. 847-853, 2006.

FRAZÃO, L. A.; SANTANA, I. K. S.; CAMPOS, D. V. B.; FEIGL, B. J.; CERRI, C. C. Estoques de carbono e 
nitrogênio e fração leve da matéria orgânica em Neossolo Quartzarênico sob uso agrícola. Pesquisa Agropecuária Brasileira, Brasília, v. 45, n. 10, p. 1198-1204, 2010.

GAZOLLA, P. R.; GUARESCHI, R. P.; PERIN, A.; PEREIRA, M. G.; ROSSI, M. G. Frações da matéria orgânica do solo sob pastagem, sistema plantio direto e integração lavoura-pecuária. Semina: Ciências Agrárias, Londrina, v. 36, n. 2, p. 693-704, 2015.

KLUTHCOUSKI, J.; OLIVEIRA, P. Benefícios da ILP para a pecuária e desafios no cultivo de grandes culturas em sistemas ILPF no Cerrado com uso de plantio direto na palha. In: SANTOS, L. F. T.; MENDES, L. R.; DUARTE, E. R.; GLÓRIA, J. R.; ANDRADE, J. M.; CARVALHO, L. R.; SALES, N. L. P. (Ed.). Integração lavoura-pecuária floresta: potencialidades e técnicas de produção. Montes Claros: Instituto de Ciências Agrárias da UFMG, 2012. p. 21-35.

LOSS, A.; PEREIRA, M. G.; ANJOS, L. H. C.; GIACOMO, S. G.; PERIN, A. Agregação, carbono e nitrogênio em agregados do solo sob plantio direto com integração lavoura-pecuária. Pesquisa Agropecuária Brasileira, Brasília, v. 46, n. 10, p. 1269-1276, 2011.

LOSS, A.; PEREIRA, M. G.; FERREIRA, E. P.; SANTOS, L. L. dos; BEUTLER, S. J.; FERRAZJUNIOR, A. S. L. Frações oxidáveis do carbono orgânico em Argissolo Vermelho-Amarelo sob sistema de aleias. Revista Brasileira de Ciência do Solo, Viçosa, MG, v. 33, n. 4, p. 867-874, 2009.

MAIA, S. M. F.; XAVIER, F. A. S.; SENNA, O. T.; MENDONCA, E. S.; ARAUJO, J. A. Organic carbon pools in a Luvisol under agroforestry and conventional farming systems in the semi-arid region of Ceará, Brazil. Agroforestry Systems, Dordrecht, v. 71, n. 2, p. 127-138, 2007.

MORAES, A. G. L.; LOSS, A.; PEREIRA, M. G.; BERNINI, T. A.; ANJOS, L. H. C.; SANTOS, L. L.; WADT, P. G. Frações oxidáveis de carbono orgânico de horizontes superficiais em topossequência sob floresta no Acre. In: FERTBIO, DESAFIOS PARA O USO DO SOLO COM EFICIÊNCIA E QUALIDADE AMBIENTAL, 2008, Londrina. Anais... Londrina: 2008. CD-ROM.

PAUL, B. K.; VANLAUWE, B.; AYUKE, F.; GASSNER, A.; HOOGMOED, M.; HURISSO, T. T.; KOALA, S.; LELEI, D.; NDABAMENYE, T.; SIX, J.; PULLEMAN, M. M. Medium-term impact of tillage and residue management on soil aggregate stability, soil carbon and crop productivity. Agriculture, Ecosystems and Environment, Netherlands, v. 164, n. 1, p. 14-22, 2013.

RAIJ, B. van; QUAGGIO, J. A. Métodos de análise de solo para fins de fertilidade. Campinas: Instituto Agronômico de Campinas, 1983. 16 p. (Circular, 63).

ROSSI, C. Q.; PEREIRA, M. G.; GIÁCOMO, S. G.; BETTA, M.; POLIDORO, J. C. Frações lábeis da matéria orgânica em sistema de cultivo com palha de braquiária e sorgo. Revista Ciência Agronômica, Fortaleza, v. 43, n.1, p. 38-46, 2012.

SALES, L. E. O.; CARNEIRO, M. A. C.; SEVERIANO, E. C.; OLIVEIRA, G. C.; FERREIRA, M. M. Qualidade física de Neossolo Quartzarênico submetido a diferentes sistemas de uso agrícola. Ciência e Agrotecnologia, Lavras, v. 34, n. 3, p. 667-674, 2010.

SALTON, J. C.; MIELNICZUK, J.; BAYER, C.; BOENI, M.; CONCEIÇÃO, P. C.; FABRICIO, A. C.; MACEDO, M. C. M.; BROCH, D. L. Agregação e estabilidade de agregados do solo em sistemas agropecuários em Mato Grosso do Sul. Revista Brasileira de Ciência do Solo, Viçosa, MG, v. 32, n. 1, p. 11-21, 2008.

SANTOS, H. G. dos; JACOMINE, P. K. T.; ANJOS, L. H. C. dos; OLIVEIRA, V. A. de; LUMBRERAS, J. F.; COELHO, M. R.; ALMEIDA, J. A. de; CUNHA, T. J. F.; OLIVEIRA, J. B. de. Sistema brasileiro de classificação de solos. 3. ed. rev. e ampl. Brasília: Embrapa, 2013. 353 p.

SILVA, V. J.; CAMARGO, R.; WENDLING, B.; PIRES, S. C. Integração lavoura-pecuária sob sistema de plantio direto no Cerrado brasileiro. Enciclopédia Biosfera, Goiania, v. 7, n. 1, p. 1-12, 2011.

SOUZA, W. J. O.; MELO W. J. Matéria orgânica em um latossolo submetido a diferentes sistemas de produção de milho. Revista Brasileira de Ciência do Solo. Viçosa, v. 27, n. 6, p. 1113-1122, 2003.

SWIFT, R. S. Organic matter characterization. In: SPARKS, D. L. (Ed.). Methods of soil analysis. Part 3. Madison: Chemical Methods SSSA, 1996. p. 1001-1069.

VALE JÚNIOR, J. F.; LEITÃO SOUSA, M. I. Caracterização e distribuição dos solos das savanas de Roraima. In: BARBOSA, R. I.; XAUD, H. A. M.; SOUZA, J. M. C. Savanas de Roraima: etnoecologia, biodiversidade e potencialidades agrosivipastoris. Boa Vista: FERMACT, 2005. 201 p.

VENDRAME, P. R. S.; EBERHARDT, D. N.; BRITO, O. R.; MARCHÃO, R. L; QUANTIN, C.; BECQUER, T. Formas de ferro e alumínio e suas relações com textura, mineralogia e carbono orgânico em Latossolos do Cerrado. Semina: Ciências Agrárias, Londrina, v. 32, n. 1, p. 1657-1666, 2011.

WALKLEY, A.; BLACK, A. An examination of the Degtjareff method for determining soil organic matter 
and a proposed modification of the chromic acid titration method. Soil Science, Baltimore, v. 37, n. 1, p. 29-38, 1934.

YEOMANS, J. C.; BREMNER, J. M. A rapid and precise method for routine determination of organic carbon in soil. Communication in Soil Science and Plant Analysis, New York, v. 19, n. 13, p. 1467-1476, 1988.
ZECH, W.; HAUMAIER, L.; HEMPFLING, R. Ecological aspects of soil organic matter in tropical land use. In: McCARTHY, P.; CLAPP, C. E.; MALCOM, R. L.; BLOOM, P. R. (Ed.). Humic substances in soil and crop sciences: selecting readings. Madison: ASA/SSSA, 1990. p. 187-220. 